\title{
Teologia i jej zadania w świetle wskazań Kongregacji Nauki Wiary
}

\begin{abstract}
In sua investigatione theologi, non aliter ac ceterarum scientiarum cultores, legitima libertate scientifica gaudent, intra tamen limites methodi sacrae theologiae, nitentes ut modo sibi proprio idem ac ipsius Magisterii propositum assequi queant, „nempe sacrum Revelationis depositum custodire, altius usque introspicere, exponere, docere, defendere: hoc est, Ecclesiae humanique generis vitam lumine divinae veritatis collustrare"1.
\end{abstract}

\section{Wolność metody teologicznej a powinności wiary}

Wydaje mi się, że aby zastanowić się nad tematem wyznaczonym przez nasze spotkanie ${ }^{2}$, trzeba postawić pytanie, którym chciałbym otworzyć naszą refleksję: czy Kongregacja Nauki Wiary jest kompetentna, by określać zadania i sposób ich podejmowania w nauce, jaką jest teologia? To pytanie wypływa z jeszcze bardziej podstawowej kwestii: w jakim sensie Kościół jest upoważniony do wskazywania

\footnotetext{
${ }^{1}$ Kongregacja Nauki Wiary, Declaratio de quibusdam capitibus doctrinae theologiae professoris Ioannis Küng, qui, ab integra fidei catholicae veritate deficiens, munere docendi, qua theologus catholicus, privatus declaratur (Deklaracja o niektórych aspektach nauczania teologicznego profesora Hansa Künga), 15 grudnia 1979, AAS 72 (1980) cpv. 2. Polska wersja dokumentów Kongregacji Nauki Wiary znajduje się na stronie www.vatican.va w sekcji Kongregacja Nauki Wiary. Documenti. Lista completa, dostępnej także pod adresem: www.doctrinafidei.va. Większość dokumentów w wersji polskiej została zebrana w tomach: W trosce o petnię wiary. Dokumenty Kongregacji Nauki Wiary, red. J. Królikowski, Z. Zimowski, t. 1 (1966-1994), t. 2 (1995-2000), Tarnów 1995-2000.

${ }^{2}$ Tekst stanowi wykład wygłoszony w czasie Międzynarodowej Posoborowe koncepcje teologii katolickiej-Post-conciliar Concepts of Catholic Theology, Uniwersytet Papieski Jana Pawła II w Krakowie, 28 lutego 2013.
} 
zadań i sposobów uprawiania teologii i określania, czym nauka ta ma być, a czym być nie powinna?

\section{Misja nauczycielska Kongregacji Nauki Wiary w Kościele}

Przede wszystkim każdemu z nas jest dobrze wiadome, czym jest Kongregacja Nauki Wiary i jakie jest jej zadanie wobec Magisterium Kościoła. To temat, którego nie mogę rozwinąć w tym miejscu, ale przyjmuję, że jest dobrze znany każdemu teologowi ${ }^{3}$. Dziś jeszcze niejedno pytanie pozostaje otwarte, chociażby to dotyczące statusu doktrynalnego coraz częstszych dokumentów tej pierwszej rzymskiej dykasterii. Przyjmujemy natomiast w pełni to, co normuje konstytucja apostolska Jana Pawła II Pastor Bonus (28 czerwca 1988), reformująca Kurię Rzymską i stanowiąca, że misją Kongregacji jest promować i strzec doktryny wiary i wszystkiego, co jest z nią związane: „Proprium Congregationis de Doctrina Fidei munus est doctrinam de fide et moribus in universo catholico orbe promovere atque tutari; proinde ipsi competunt ea, quæ hanc materiam quoquo modo attingunt" ". Co więcej, przyjmujemy nauczanie instrukcji Donum veritatis, która w numerze 18 mówi:

W spełnianiu powszechnej misji Biskupowi Rzymu pomagają urzędy Kurii Rzymskiej, a w tym, co odnosi się do spraw wiary i moralności, jest on wspierany szczególnie przez Kongregację Nauki Wiary. Wynika z tego, że dokumenty tej Kongregacji osobiście zatwierdzone przez Papieża wchodzą w zakres zwyczajnego nauczania następcy Piotra5.

\section{Wolność naukowa teologii}

Z drugiej strony, przyjmujemy w pełni przywołane powyżej stwierdzenie jednej z deklaracji Kongregacji, w którym to Urząd zapewnia, że „teologowie w swoich badaniach, tak jak przedstawiciele innych nauk, korzystają z uprawnionej wolności naukowej, jednak w granicach metody świętej teologii". Wolność nauk teologicznych jest porównywalna z wolnością każdej innej nauki, ale jednocześnie jest

${ }^{3}$ Pozwalam sobie odesłać do mojej publikacji: L'insegnamento postconciliare della Congregazione per la Dottrina della Fede. Un panorama attraverso i generi letterari, Alpha Omega XIV, 3 (2011), s. 325-358.

${ }^{4}$ Jan Paweł II, konst. Pastor Bonus, 48.

${ }^{5}$ „Romanus Pontifex missionem suam universalem adimplet auxilio institutorum Curiae Romanae, peculiarique modo Congregationis pro Doctrina Fidei quod attinet ad doctrinam fidei et morum. Exinde sequitur documenta huius Congregationis, expresse a Romano Pontifice approbata, participare Magisterium ordinarium successoris Petri”.

${ }^{6}$ Por. przypis 1. 
ona wyznaczona $w$ ramach metody właściwej nauce teologicznej. W tym świetle wydaje się, że wskazań, zadań i zasad teologii należy szukać przede wszystkim już na poziomie samej jej metody naukowej. Wewnętrzna struktura teologii jako scientia sacra i sacra doctrina jest pierwszą miarą i wskazaniem zadania teologii w Kościele.

\section{Wspólny cel Urzędu Nauczycielskiego Kościoła i teologii}

Co więcej, zacytowany tekst Kongregacji, odwołując się do słynnego przemówienia sługi Bożego Pawła VI Libentissimo sane na kongresie poświęconym teologii Soboru Watykańskiego II ${ }^{7}$, dodaje, że podstawowym zadaniem teologów jest

staranie się dojść, we właściwy im sposób, do tego samego celu, co Urząd Nauczycielski, czyli: „zachowywać, coraz głębiej przenikać, wykładać, nauczać, bronić świętego depozytu objawienia; oświecać więc życie Kościoła i ludzkości za pośrednictwem prawdy Bożej”.

W istocie zadanie teologii jest takie samo jak zadanie Magisterium, obu przyświeca ten sam cel i podobna odpowiedzialność wobec słowa Bożego. I teologia, i Magisterium są oddane niejako tej samej służbie, która je ściśle ze sobą łączy i upodabnia pod względem celów, jakim służą, każde jednak we właściwy sobie sposób.

Urząd Nauczycielski otrzymuje swoją władzę na mocy święceń sakramentalnych, które ,udzielają również misji nauczania i rządzenia". [...] Teologowie posiadają władzę specyficznie teologiczną na podstawie ich kwalifikacji naukowych. Ta władza nie może być jednak oddzielona od natury teologii jako nauki wiary, która nie może być uprawiana bez żywego doświadczenia i praktykowania wiary ${ }^{8}$.

Obie te katedry, Magisterium i teologia, jak mówi o nich św. Tomasz z Akwinu, magisterium cathedrae pastoralis i magisterium cathedrae magisterialis ${ }^{9}$, zacho-

\footnotetext{
${ }^{7}$ Paweł VI, Allocutione ad Congressum Internationalem de Theologia Concilii Vaticani II, 1 października 1966, AAS 58 (1966), s. 890. Na kanwie tego przemówienia Międzynarodowa Komisja Teologiczna przygotowała swój dokument Urząd Nauczycielski Kościoła i teologia, opublikowany w 1975 roku.

${ }^{8}$ Międzynarodowa Komisja Teologiczna, Urząd Nauczycielski Kościoła i teologia, teza 6.

${ }^{9}$ Contra impugnantes, c. 2; Quodlib. III, q. 4 a. 1 (9); In IV Sent., 19, 2, 2, q. 3 sol. 2 ad 4; por. Kongregacja Nauki Wiary, Instrukcja Donum veritatis o powołaniu teologa w Kościele, 24 maja 1990, AAS 82 (1990), 34. Na temat Donum veritatis można odesłać do komentarzy: J. Ratzinger, Introduzione all 'istruzione „Donum veritatis”, „Gregorianum” 78 (1997) $\mathrm{nr}$ 2, s. 219-221; A. Anton, I teologi davanti all 'istruzione „Donum veritatis”, „Gregorianum” 78 (1997) nr 2, s. 223-265; tenże, Il compito ,ecclesiale” e „scientifico” del teologo nell 'istruzione „Donum veritatis”, „Civiltà Cattolica” 148 (1997) nr 3, s. 365-376; tenże, Il ruolo di ,mediazione” del teologo nell'istruzione „Donum veritatis”, „Civiltà Cattolica” 148 (1997) nr 4, s. 117-130. Natomiast o samej relacji Magisterium
} 
wujące swoją specyfikę i różnice, nie mogą być wobec siebie ani konkurencją, ani drogami paralelnymi, bo istnieją dla tego samego celu. Obie te katery potrzebują siebie nawzajem. Teologia potrzebuje Magisterium, Magisterium potrzebuje teologii. Kościół potrzebuje kompetencji Magisterium i teologii. Gdyby zabrakło równowagi obu tych kompetencji, nastąpiłoby niebezpieczne zachwianie całej harmonii doctrina et inteligentia fidei. Magisterium do realizowania swych kompetencji potrzebuje zdrowej i żywej teologii, tak jak teologia do bycia w pełni kompetentną wymaga Magisterium.

\section{Pierwszeństwo prawdy Chrystusa}

W tym świetle można stwierdzić, że zadania i teologii, i Magisterium są obojgu wskazane, naznaczone nie tyle przez ich wzajemne relacje, co raczej z instancji wyższej, która dla obu tych autorytetów, naukowego i pasterskiego, określa jeden $\mathrm{i}$ ten sam cel do osiągnięcia. To właśnie sam cel teologii, ten sam, który przyświeca Magisterium, jest nieodzowną i pierwszorzędną wskazówką, albo - mówiąc ściślej - normą, zasadą i kryterium teologii w każdym miejscu i w każdym czasie. Owa norma, zasada i kryterium jest jedna i ta sama dla teologii i dla Magisterium.

Definitywnym wyznacznikiem drogi teologii i Kościoła jest bowiem tylko Słowo Wcielone, Jezus Chrystus, jedyny - w pełnym tego słowa znaczeniu - wierny „Teolog” całego Objawienia, które w sobie niesie, „Egzegeta” Przymierza, który ukazał sens pism Starego Przymierza, jedyny w pełni tego słowa znaczeniu „Pasterz” całego Kościoła. Można powiedzieć, że natura tego, czym jest teologia, została ukazana już w Słowie Wcielonym i w relacji Jego osoby i misji do Ojca objawiającego i do Starego Testamentu wypełnionego we Wcieleniu.

Tylko w tym chrystologicznym sensie Kościół ma prawo przez swoje kompetentne struktury ukazywać sens i zasady teologii na tyle, na ile zostały one objawione i wcielone przez prototyp teologa, jaki został dany w Jezusie i rozwinięty przez Tradycję Jego Kościoła. W takiej perspektywie trzeba postrzegać instrukcję Donum veritatis o powołaniu teologa $\mathrm{w}$ Kościele, której punktem wyjścia nie jest ani teologia, ani Magisterium, ale dar prawdy: „Donum veritatis, quae nos liberos efficit, Iesus Christus elargitus est (por. J 8, 32) - Prawda, która wyzwala, jest darem Jezusa

\footnotetext{
i teologii istnieje dziś imponująca literatura, możemy tu przywołać tylko kilka prac: A. J. Figueiredo, The Magisterium - Theology Relationship. Contemporary Theological Conceptions in the Light of Universal Church Teaching since 1835 and the Pronouncements of the Bishops of the United States, Roma 2001; D. Le Tourneau, L'adhésion au Magistère ecclésiastique, „Studia Canonica” 46 (2012), s. 51-74; G. Colombo, Magistero e teologia, „Teologia” 4 (1991), s. 291-305; F. Ardusso, Magistero ecclesiale. Il servizio della Parola, Cinisello Balsamo 1997; tenże, La funzione del Magistero. Problemi e orientamenti della teologia contemporanea, [w:] Rivelazione e Magistero, Brescia 1973; T. Citrini, Il magistero: aspetti teologici e giuridici, [w:] La funzione di insegnare della Chiesa, Milano 1994.
} 
Chrystusa (por. J 8, 32)" "10. Prawda Syna objawiającego ma absolutne pierwszeństwo przed Kościołem z jego pasterskim nauczaniem doktrynalnym i z refleksją naukową jego teologów. I pasterze, i teologowie pozostają na służbie tej Prawdy ${ }^{11}$, a ta od wszystkich wymaga pokornej i roztropnej służby.

\section{Naturalna powściągliwość Kościoła w sprawach metody i jej korzenie objawione}

Wydaje mi się, że w perspektywie chrystologicznej można doszukiwać się racji, dla których Kościół był raczej z natury zawsze powściągliwy i bardzo ostrożny w wydawaniu wskazań i pouczeń na temat tego, jak uprawiać teologię, jaką teologia powinna obrać metodę. Kościół przez swoje sobory i nauczanie następców apostoła Piotra jest upoważniony i wprawiony przez wieki do poprawiania i naprawiania błędów doktrynalnych ${ }^{12}$, jest powołany do naprawiania ewentualnych herezji. W tej swojej misji nieczęsto jednak wypowiadał się, jak uprawiać teologię, nie nauczał zbyt wiele o jej metodologii, o hermeneutyce teologii. Można powiedzieć, że w przeszłości metoda teologii widziana była raczej jako coś oczywistego, przypisanego samej naturze pracy teologicznej, bez której teologia nie byłaby sobą. Mówiąc bardziej obrazowo, trzeba było czasem w przeszłości poprawić, niejedną zresztą, herezję

${ }^{10}$ Kongregacja Nauki Wiary, Instrukcja Donum veritatis, 1 . Taka sama perspektywa priorytetu prawdy, i prawdy objawionej w szczególności, otwierała już wcześniejsze instrukcje kongregacji: incipit instrukcji Libertatis nuntius o niektórych aspektach teologii wyzwolenia z 6 sierpnia 1984 roku głosił: „Ewangelia Jezusa Chrystusa jest orędziem wolności i mocą wyzwalającą” (1), natomiast Liberatis conscientia o chrześcijańskiej wolności i wyzwoleniu z 22 marca 1986 roku jeszcze przed otwarciem dokumentu słowami: „Świadomość wolności i godności, idąca w parze z uznaniem niezbywalnych praw osoby i społeczeństw, jest jedną z głównych cech charakteryzujących nasze czasy" (1) wieńczył tekst mottem: „Prawda was wyzwoli”, prawda, która otwiera na to wszystko, co pozostaje „w zgodzie z prawdą o człowieku, jaka ujawnia się w świetle jego stworzenia i odkupienia” (1). Trzeba przyznać, że obie instrukcje są nader interesujące także ze względu na kwestie metodologiczne badań teologicznych. Nie można też zapomnieć o siódmej części instrukcji Libertatis nuntius, która dotyczy analizy filozofii marksistowskiej w teologii wyzwolenia (VII, 1-13), wraz z konsekwentną analizą proponowanej nowej hermeneutyki (por. X, 1-16), albo o wskazaniach dotyczących priorytetu wiary w Libertatis coscientia, 96, itd. Por. A. López Trujillo, Liberación marxista y liberación cristiana, Madrid 1974.

${ }^{11}$ Być może, gdyby w refleksji nad recepcją nauczania Soboru Watykańskiego II więcej rzetelnej uwagi poświęcono chrystologicznej strukturze całego nauczania soborowego, nie doszłoby do tak wielu nadinterpretacji albo interpretacji błędnych, jakich byliśmy świadkami w dziesięcioleciach posoborowych. Bez wątpienia wymiar chrystologiczny nauczania Soboru Watykańskiego II musi być dziś na nowo odkryty i poddany refleksji.

${ }^{12}$ Wydaje się tu ważne rozróżnienie między tym, co teologiczne, i tym, co doktrynalne. Kościół ma obowiązek poprawiać błędy doktrynalne z puntku widzenia doktryny wiary. To jest ten sam punkt widzenia, który obowiązuje katedrę teologii w jej rozeznawaniu prawdy. Trzeba dziś jasnego rozeznania różnicy między doktryną wiary a teologią. 
chrystologiczną, ale fakt używania przez teologów metody właściwej ich nauce wydawał się raczej niepodważalny.

W rzeczywistości metoda teologii wypływa $\mathrm{z}$ dynamiki Wcielenia i w samej swej istocie może być widziana jako część Objawienia. Wystarczy wspomnieć te elementy sposobu myślenia teologicznego, które zawarte są już w Nowym Testamencie, a którym wierni byli pierwsi teologowie chrześcijańscy: apostoł Paweł i ewangelista Jan. Można wymienić tu przynajmniej kilka podstawowych kryteriów, którym teologia musi pozostawać wierna, a które to koordynują refleksję teologiczną autorów pism Nowego Testamentu, takich właśnie jak Paweł i Jan: 1) kerygma (śmierć i zmartwychwstanie Jezusa Chrystusa); 2) depositum fidei; 3) pisma Starego Testamentu; 4) znaki Ducha Świętego, przez które działa On we wspólnocie Kościoła (znaki czasu); 5) lex orandi jako norma wiary; 6) autorytet apostolski i soborowy; 7) sensus fidelium; i wreszcie 8) rozum (recta ratio) ${ }^{13}$. To są podstawowe elementy koordynujące metodę, świadczące o kompetencji i wolności tej nauki kościelnej, zakorzenionej w Piśmie Świętym.

Wydaje mi się, że powściągliwość Kościoła w wypowiadaniu się o metodzie teologii tu znajduje swoje podłoże. By nie być źle zrozumianym, zreasumuję raz jeszcze hipotezę tu stawianą. Kościół w swoim Urzędzie Nauczycielskim jest powołany do autentycznej interpretacji Objawienia i do poprawiania błędów z nią związanych, gdy to konieczne. To też czyni na przestrzeni wieków, o wiele rzadziej zaś w przeszłości, jeśli mnie pamięć nie myli, wypowiadał się na temat metody, czyli wskazań, jak uprawiać teologię. Owa powściągliwość jest wyrazem respektu dla kompetentnej wolności nauki teologicznej, a jednocześnie znakiem świadomości Magisterium, że wolności myślenia teologicznego przyświeca dokładnie ten sam cel objawiony, któremu służy i Urząd Nauczycielski Kościoła.

\section{Proces odnowionej odpowiedzialności kościelnej za metodę teologii}

Bezpośrednie historyczne racje tego stanu rzeczy, motywy owej powściągliwości w określaniu metody teologicznej przez Kościół chciałbym nakreślić za chwilę. Teraz pozwolę sobie tylko wspomnieć, że w czasach nam bliższych można jednak zauważyć pewien zdecydowany rozwój tego stanu rzeczy, rozwój sposobu, w jaki

${ }^{13}$ Dla historii metody teologicznej por. C. Delpero, La teologia nella storia. Genesi ed evoluzione del metodo teologico, Firenze 2001, 2004²; L. Martínez, Los caminos de la teológia. Historia del método teológico, Madrid 1998, jak również: Pontificia Accademia di Teologia, Il metodo teologico oggi. Fra tradizione e innovazione, „Path” 1 (2004); Il metodo teologico oggi-II. Comunicare in Cristo tra memoria e dialogo, „Path” 1 (2006); Il metodo teologico. Tradizione e innovazione. Comunione in Cristo, a cura di M. Sodi, Città del Vaticano 2008. 
Kościół traktuje kwestię metody teologicznej, a co za tym idzie, eklezjalną odpowiedzialność za to, jak należy uprawiać teologię. W czasach nam bliższych wydaje się bowiem, że Kościół jakby częściej i bardziej uroczyście zaczął się wypowiadać na temat metod teologii.

Chciałbym więc naszkicować kilka decydujących elementów rozwoju nauczania Kościoła w tej sferze w czasach nowożytnych, poczynając od soborów watykańskich i na ostatnich dokumentach Kongregacji Nauki Wiary kończąc.

\section{Nowożytny rozwój relacji Kościoła do metody teologicznej}

Nauczanie dwóch soborów watykańskich

Po raz pierwszy chyba w historii chrześcijaństwa dopiero dwa nowożytne sobory dotknęły w szerszym kontekście kwestii metody teologicznej. O ile Sobór Watykański I czynił to z punktu widzenia Objawienia Bożego (Dei Filius), to Sobór Watykański II podejmował tę samą problematykę, wychodząc od podmiotu ludzkiego teologii i skupiając się na formacji kapłańskiej (Optatam totius) i na dialogu ekumenicznym (Unitatis redintegratio).

1. Jak wiadomo, Sobór Watykański I aprobuje w formie definitywnej Constitutio dogmatica Dei Filius de fide catholica 24 kwietnia 1870 roku, nauczając i definiując doktrynalnie teologię jako intelligentia fide $i^{14}$. W poznaniu, jakim jest teologia, w intelligentia Sobór dostrzega działanie rozumu, pracę ratio. Ta ratio, naturalna zdolność spekulatywna człowieka, może stać się podmiotem wciąż nowego poznania. W teologii rozum człowieka wierzącego kieruje się na wymiar nadprzyrodzony. Przyjmując i penetrując intelektualnie tę rzeczywistość, dochodzi do jej coraz głębszego poznania. Poznanie to nie jest oczywiście wynikiem tylko ludzkich sił rozumu, nie jest owocem samej tylko inteligencji, jak to jest w przypadku filozofii. Nie chodzi bowiem o naturalne tylko poznanie rzeczywistości. Sobór Watykański I precyzuje bowiem, że poznanie teologiczne, poznanie rzeczywistości nadprzyrodzonych, następuje zawsze Deo dante (przez dar Boga). W pełni mamy tu do czynienia $\mathrm{z}$ ratio, ale jest to ratio fide illustrata (rozum oświecony przez wiarę). W ten sposób dostrzegamy pierwszą różnicę między filozofią i teologią naturalną, filozoficzną częścią teologii, którym wystarcza sam rozum, a teologią w sensie ścisłym. Sobór uczył nas, że w wierze i poprzez wiarę dochodzi się do poznania rzeczywistego, w pełnym tego słowa znaczeniu, i do poznania wciąż nowego. Jest to intelligentia fidei, zrozumienie wiary, które jest sercem, duszą teologii. Nie chodzi tu o jakiś intelektualizm, ale całe poznanie, o którym uczy Sobór Watykański I, postrzega

${ }^{14}$ Enchiridion Symbolorum 3015-3016: rozdział 4. Wiara i rozum. 
teologię raczej jako sapientia. W teologii do intelligentia fidei dochodzi się tylko wtedy, jeśli naukowo kompetentny ochrzczony przyjmie postawę sedulo, pie et sobrie (z gorliwością, pobożnością i umiarkowaniem). Są to trzy przymiotniki, które określają teologa w każdym czasie, także w naszej chwili historycznej: żarliwość, pobożność i umiarkowanie. Wymiar mądrościowy teologii jako eklezjalnej nauki wiary wydaje się ewidentny, jak to ostatnio przypomnieli teologowie Międzynarodowej Komisji Teologicznej w dokumencie Teologia dzisiaj ${ }^{15}$.

Sobór nakreśla jeszcze trzy drogi, którymi można dojść do tejże intelligentia fidei. Zrozumienie wiary następuje w trojaki sposób:

1. Po pierwsze, jako analogica intelligentia. Zrozumienie wiary jest analogiczne: posługuje się analogią do tego, co zna w sposób naturalny, ale w ten sposób analogia nie może nigdy dotrzeć do całkowitej identyczności, bo naznaczona jest przez różnorakie różnice. Niemniej jest to rzeczywista, realna droga poznania, która pogłębia prostą wiarę, przybliża tajemnice wiary objawionej ludzkiemu zrozumieniu i czyni je dostępnymi, używając pojęć poznanych w sposób naturalny. Nie jest to zamknięcie wiary w ramach intelektualizmu i nie jest to rozświetlenie tejże wiary mocą umysłu, dlatego że różnica pozostaje zawsze większa od podobieńtwa, jakie rozum może uchwycić między tym, co nadprzyrodzone, i tym, co przyrodzone. W tym kontekście Tomasz z Akwinu mówił o „tenebra ignorantiae”, która zawsze pozostaje $\mathrm{w}$ umyśle ${ }^{16}$.

Według Soboru intelligentia fidei może być zdobyta także na innej drodze 2): „ex contextu, quo veritates inter se [...] connectuntur” (z relacji, jaka istnieje między prawdami doktrynalnymi wiary). Tajemnice wiary objawionej mogą być oświecone i przybliżone ludzkiemu poznaniu dzięki relacji, jaka istnieje między nimi, która ukazuje, jak pojedyncza prawda odnosi się do innych prawd i do całości Objawienia (nexus mysteriorum inter se).

Podmiotem takiego zrozumienia wiary jest wciąż „umysł oświecony wiarą i rezultatem" i w tym przypadku aliqua intelligentia fidei. Nowością w tym poznaniu jest fakt, że nie odnosi się do analogii naturalnej - cały proces poznania dokonuje się w ramach wiary, w granicach samych tajemnic wiary. Umysł rozpoznaje, jak jedna prawda wiary pozostaje $\mathrm{w}$ relacji do innej prawdy, jak jedna prawda jest podstawą dla innej, warunkiem albo przyczyną, ale i konsekwencją czy efektem. Także ta forma poznania wiary pozostaje wciąż w tej ciemności, o której mówił Tomasz. Tyle że mamy tu do czynienia już nie z poznaniem naturalnym, ale z analogia fidei - analogią, która pozostaje w granicach Objawienia. Konstutucja Dei Verbum (18 listopada 1965) Soboru Watykańskiego II w numerze 12. podejmuje dokładnie ten sam temat, gdy naucza:

\footnotetext{
${ }^{15}$ Por. nr 86-99: Nauka i madrość.

${ }^{16}$ In I Sent., dist. 8., q. 1, a. 1.
} 
ponieważ Pismo Święte powinno być czytane i interpretowane w tym samym Duchu, w jakim zostało napisane, należy, celem wydobycia właściwego sensu świętych tekstów, nie mniej uważnie także uwzględnić treść i jedność całej Biblii, mając na oku żywą Tradycję całego Kościoła oraz analogię wiary (ratione habita vivae totius Ecclesiae Traditionis et analogiae fidei).

Wreszcie 3) Sobór Watykański I w Dei Filius mówi, że zrozumienie wiary następuje „ex mirabili congruentia, qua (veritates) cum fine nostra (fine hominis) ultimo connectuntur", to znaczy, że fascynująca relacja, jaka istnieje między samymi prawdami wiary, istnieje także między nimi samymi i celem ostatecznym człowieka (fine hominis). Człowiek w swoim poznawaniu siebie i świata nieraz doświadcza tego, że widzi wiele rzeczy, wiele fragmentów, a nie widzi całości, nie dostrzega harmonii rzeczywistości w jej całości, w całościowym jej kształcie. To może zdarzyć się też w teologii, gdy dostrzegamy i znamy wiele detali, a nie ogarniamy wizji całości doktryny wiary, jej wewnętrznego porządku i harmonii. Taki problem i ryzyko fragmentaryzacji są bardzo bliskie współczesnej mentalności i współczesnym naukom, od medycyny poczynając, a na teologii kończąc. Sobór Watykański I wskazuje drogę do tego, jak dojść do wizji całości i nie zatracić żadnej prawdy: należy obrać punkt odniesienia, od którego pada światło na całość prawd. Jako punkt odniesienia pokazany jest cel ostateczny człowieka, jego finis ultimus, który można określić jako zbawienie w Bogu, bycie w Chrystusie, oglądanie wieczne Bożego oblicza itp. Takim celem ostatecznym nie może być ani pokój między narodami, ani walka z ubóstwem, ani porządek polityczny, ani sprawiedliwość ziemska, kóre są oczywiście celami ludzkiego działania, ale nie są celami ostatecznymi. To wszystko jest ważne także dla teologa, ale nie może stanowić celu ostatecznego człowieka, od którego należy wychodzić, żeby zrozumieć i studiować relację istniejącą między tajemnicami wiary a człowiekiem szukającym zbawienia.

Dla teologii jest rzeczą nieodzowną, żeby taki punkt odniesienia został wybrany albo, precyzyjniej, przyjęty od samego Objawienia. Teologia wymaga wizji całości doktryny, która pozwala na większe i lepsze zrozumienie niż poznanie tylko sumy mnogości detali i fragmentów. Niemniej ważne jest, by ten punkt odniesienia był właściwy, bo to determinuje drogi poznania teologicznego. Można powiedzieć, że ojcowie Soboru Watykańskiego II nie mieli wątpliwości, że takim punktem odniesienia jest Chrystus, Słowo Wcielone. Potwierdza to cały Sobór przeniknięty w swoim nauczaniu chrystocentryzmem.

2. Bez wątpienia Sobór Watykański II wskazywał coś bardzo podobnego, gdy wzywał teologów do rozpoznania „hierarchii prawd” doktryny katolickiej (dekret Unitatis redintegratio, 21 listopada 1964, nr 11), którą należy dobrze zrozumieć, nie zatracając z pola widzenia analogia fidei, o której oba sobory watykańskie nauczały (Dei Filius i Dei Verbum). „Hierarchia prawd” musi być widziana jako strukturalne uporządkowanie tego, co w wierze centralne, i tego, co podporządkowane, bardziej peryferyjne; tego, co jest centrum wiary, i tego, co owo centrum pogłębia i lepiej 
oświetla, co oznacza, że nie może być wyeliminowane albo postrzegane jako fakultatywne czy tylko opcjonalne, bo dane jest dla wyrażenia głębi całego depozytu wiary. Takie podejście byłoby poważnym błędem metody teologicznej, który już niestety nieraz dał się zauważyć w ostatnich czasach, kiedy analogię wiary przeciwstawiano chętnie hierarchia veritatum. Dekret soborowy Unitatis redintegratio nakazuje:

teologowie katoliccy [...] przy zestawianiu doktryn niech pamiętają o istnieniu porządku czy „hierarchii” prawd w nauce katolickiej, ponieważ różne jest ich powiązanie z zasadniczymi podstawami wiary chrześcijańskiej (In comparandis doctrinis meminerint existere ordinem seu „hierarchiam” veritatum doctrinae catholicae, cum diversus sit earum nexus cum fundamento fidei christianae),

a to wszystko dla głębszego poznania i jaśniejszego ukazania niedościgłych bogactw Chrystusowych. Sobór Watykański II mówi o fundamentum fidei christianae, co przywołuje na myśl ten punkt odniesienia, cel ostateczny całej teologii, o jakim nauczał Sobór Watykański I, który to pozwalał dostrzec całość doktryny w jej harmonijnym uporządkowaniu. W zależności od tego punktu odniesienia zmieniałaby się wizja całości doktryny. Inaczej będzie ona bowiem pojmowana, jeśli jej celem ostatecznym będzie Chrystus, inaczej natomiast, jeśli taki punkt odniesienia będzie widziany w ubogich, anavim, jak o nich mówi Pismo. Inaczej, jeśli jej centrum jest Bóg, inaczej, jeśli takim centrum stałaby się ludzkość.

3. Nauczanie posoborowe i recepcja teologiczna Soboru w sprawie metody teologicznej podjęły przede wszystkim rekomandacje soborowe zawarte w Dekrecie Optatam totius o formacji kapłańskiej (28 października 1965), z jego słynnym tekstem o nauczaniu teologii zawartym w numerze 16. Optatam totius może być widziane jako syntetyczne przywołanie elementów właściwej metody teologii katolickiej, jako zakorzenionej w Słowie Bożym, podjętym przez żywą tradycję Kościoła, w jej relacji do innych nauk, nie zatracając całkowicie jako mistrza sacra doctrina Tomasza z Akwinu w tym sensie, że jego zdolność syntezy pozostaje dla metody teologicznej czymś nieodzownym i uniwersalnym ${ }^{17}$, co nie znaczy, że można zaniechać konfrontacji z wciąż nowymi szkołami i tendencjami metodologicznymi i filozoficznymi ${ }^{18}$.

${ }^{17}$ Por. K. Charamsa, San Tommaso d'Aquino, maestro della formazione sacerdotale, [w:] Percorsi di formazione sacerdotale, a cura di G. Borgonovo, K. Charamsa, t. 1, Città del Vaticano 2005, s. 158-174.

${ }^{18}$ Dla zilustrowania refleksji nad metodą teologiczną w duchu soborowym można odesłać do takich autorytetów, jak: G. Philips, Los métodos teológicos del Vaticano II, [w:] Al servicio teológico de la Iglesia. Homenaje a Y. Congar, Santander 1975, s. 13-36; K. Rahner, Theologische Erkenntnis- und Methodenlehre, [w:] ,Sacramentum mundi”. Theologisches Lexikon für die Praxis, t. 4, Freiburg 1969, s. 885-892; W. Kasper, Die Methoden der Dogmatik. Einheit und Vielheit, München 1967; J. Ratzinger, Das Problem der Dogmengeschichte in der katholischen Theologie, Münster 1971; tenże, Natura e compito della teologia. Il teologo nella disputa contemporanea. Storia e dogma, Milano 
W duchu tego nauczania soborowego błogosławiony Jan Paweł II dwa razy w sposób uroczysty podejmował temat metody teologicznej: ogólnie, w jej relacji do filozofii i nauki, w encyklice Fides et ratio $(1998)^{19}$, i szczegółowo, skupiając się na metodzie jednej tylko dziedziny teologicznej, jaką jest teologia moralna, w encyklice Veritatis splendor $(1993)^{20}$.

4. Te nowożytne wskazania Kościoła wydają mi się pewną nowością w stosunku do przeszłości, kiedy znacznie rzadziej Kościół wypowiadał się na temat metody teologicznej. Jak wspominaliśmy, przyczyną takiego stanu rzeczy był fakt, że metoda należy do tych spraw podstawowych, które wypływają z samej natury chrystologicznej wiary, a należą niepodważalnie do myśli chrześcijańskiej.

Niemniej, gdy zastanowić się głębiej, Ariusz prezentował w swojej myśli nie tylko błędy doktrynalne, które Kościół zdołał skutecznie przezwyciężyć, ale też - można powiedzieć -sama jego metoda była błędna, jego interpretacja tekstów Pisma pozostawiała wiele do życzenia. Jednak tym, co Kościół poprawiał, nie była w pierwszym rzędzie metoda naukowca, ale błędy doktrynalne, herezje Ariusza. Sądzę, że w myśli przeszłości jasne było przekonanie, że poprawiać metodę naukową znaczyłoby podważyć samą kompetencję naukowca. To tak jakby powiedzieć teologowi, że posiada luki w formacji naukowej. To oznaczałoby nie tyle dyskwalifikcaję doktrynalną stawianych tez, ile podważenie jego kompetencji jako teologa naukowca. Kto nie posiadł metody, nie jest zdolny podejmować wezwań nauki, której chce służyć. Stąd wynikałoby, że nie warto nawet zajmować się tezami stawianymi przez kogoś, kto nie jest kompetentny, i obalać ich jako herezji. Byłaby to swego rodzaju strata czasu.

Owszem, zdarzało się w przeszłości nieraz, że krytyka pozycji heretyckich zaczynała się od opłakania ignorancji heretyka. Wystarczy wspomnieć najsłynniejszy

1993; O. González de Caredal, El quehacer de la teología, Salamanca 2008; M. Seckler, Theologie als Glaubenswissenschaft, [w:] Handbuch der Fundamentaltheologie, t. 4: Traktat Theologische Erkenntnislehre, Tübingen-Basel 20002, s. 131-184; B. Welte, Ein Vorschlag zur Methode der Theologie heute, [w:] Auf der Spur des Ewigen, Freiburg 1965, s. 416-419; J. Wicks, Introduzione al metodo della teologia, Casale Monferrato 1994; G. Pozzo, R. Fisichella, Metodo in teologia sistematica e fondamentale, [w:] Dizionario di teologia fondamentale, a cura di R. Latourelle, Assisi 1990, s. 724-748.

${ }^{19}$ W Fides et ratio papież mówił między innymi o metodzie teologii: „Struktura teologii jako nauki wiary ukształtowana jest przez podwójną zasadę metodologiczną: auditus fidei i intellectus fidei. W świetle pierwszej z nich teologia przyswaja sobie treści Objawienia, w miarę jak są one stopniowo wyjaśniane przez Świętą Tradycję, Pismo Święte i żywy Urząd Nauczycielski Kościoła. Stosując drugą zasadę, teologia stara się spełnić specyficzne wymogi rozumu przez refleksję spekulatywną" (65). Można przez auditus fidei i intellectus fidei odkryć odniesienie do teologii pozytywnej (auditus fidei) skupione w pierwszym rzędzie na źródłach prawdy teologicznej i teologii spekulatywnej (intellectus fidei), proponującej refleksję nad wiarą podaną w źródłach dotyczących Objawienia. Teologia pozytywna bez spekulatywnej ryzykowałaby swoisty formalizm myśli, tak jak spekulatywna traciłaby pewny grunt myślenia bez rzetelnego wykładu pozytywnego źródeł.

${ }^{20}$ Por. Jan Paweł II, enc. Veritatis splendor, AAS 85 (1993), 1133-1228. 
list Leona Wielkiego do Flawiana, najważniejszy dokument chrystologii Zachodu. Papież pisał w nim na samym wstępie o Eutychesie, że to człowiek, którego poglądy ukazały to, czym jest: człowiekiem nieroztropnym, o którym można powiedzieć to, co Pismo mówi w słowach Psalmu: „nie chciał rozumieć, aby dobrze czynił. Na swoim łożu zamyśla nieprawość, wkracza na niedobrą drogę, nie stroni od złego" (Ps 36, 3-4). Co więcej, według papieża Leona błędy Eutychesa wynikały z jego ignorancji, nieznajomości samego apostolskiego Wyznania wiary ${ }^{21}$.

Jeszcze wcześniej, z nie mniejszym zaangażowaniem emocjonalnym, wielki Orygenes krytykował ignorancję metodologiczną i naukową, kiedy poprawiał bez wątpienia błędne tezy ebionitów negujących bóstwo Chrystusa. Orygenes wiedział, że są oni nazywani ebionitami od hebrajskiego słowa ebionim (ubodzy), ale thumaczył, że ten ich przydomek to tylko dowód na to, że są „ubodzy w rozumieniu”"22. Jednym słowem, uznawał swoich przeciwników za niekompetentnych, z brakami na poziomie intelektualnego zrozumienia spraw wiary, ubogich na poziomie naukowym. Można przyjąć, że jest to swego rodzaju krytyka metody rozumowania.

Czasy nowożytne przyniosły nową refleksję, ale i nowe problemy związane z metodą, która do tej pory nie stawiała problemów aż tak ważnych, by Kościół musiał się uroczyście i częściej wypowiadać na jej temat. Do tej pory metoda teologiczna była postrzegana bardziej jako kwestia kompetencji wynikającej z samej istoty teologii, bez której nauka ta nie mogłaby istnieć. Przez wieki była oczywiście prowadzona dyskusja na temat metody, ale ta nie wymagała wciąż ponawianych interwencji Kościoła. Dyskusja pozostawała w granicach istoty teologii jako nauki wiary. Tak powstały dzieła „metodologów” teologii starożytności i scholastyki: Wincentego z Lerynu († 450) ${ }^{23}$ i Melchiora Cano $(1509-1560)^{24}$. Tak też Tomasz z Akwinu lansował nową metodę za pomocy metafizyki arystotelesowskiej.

Przypominają się słowa Maxa Webera (1864-1920):

Der Dilettant unterscheidet sich vom Fachmann nur dadurch, daß ihm die feste Sicherheit der Arbeitsmethode fehlt, und daß er daher den Einfall meist nicht in seiner Tragweite nachzukontrollieren und abzuschätzen oder durchzuführen in der Lage ist ${ }^{25}$.

${ }^{21}$ Por. Leon Wielki, List 28 do Flawiana, Biskupa Konstantynopola, rozdz. 1.

${ }^{22}$ Orygenes, Peri Archon IV, 3, 5. 8; In Mt. com. ser. 79.

${ }^{23}$ Por. Wincenty z Lerynu, Commonitorium, 2, 3; 3, 20-23.

${ }^{24}$ Por. M. Cano, De locis theologicis libri duodecim, opera pubblicata postuma nel 1563; B. Körner, Melchior Cano, „De locis theologicis”. Ein Beitrag zur theologischen Erkenntnislehre, Graz 1994; J. Belda Plans, Melchior Cano, „De locis theologicis”, Madrid 2006; por. M. Seckler, Die ekklesiologische Bedeutung des Systems der , loci teologici”. Erkenntnistheoretische Katholizität und strukturale Weisheit, [w:] tenże, Die schiefen Wände des Lehrhauses, Freiburg-Basel-Wien 1988, s. 79-104.

${ }^{25}$ M. Weber, La scienza come professione (Wissenschaft als Beruf), a cura di P. Volonté, Milano 1997, s. 78-79. 
Tym, co różni dyletanta, ale i początkującego naukowca od specjalisty, jest pewne posiadanie metody, która pozwala na kontrolowanie idei i stawianych tez i ocenianie ich znaczenia. Pewnie, dodaje Weber: „Der Einfall ersetzt nicht die Arbeit. Und die Arbeit ihrerseits kann den Einfall nicht ersetzen oder erzwingen, so wenig wie die Leidenschaft es tut. Beide - vor allem: beide zusammen - locken ihn".

Idea, genialny pomysł nie zastąpi metodycznej pracy. Sama praca nie może zastąpić idei, nie może zastąpić zamiłowania, pasji. Oba, i praca, i zamiłowanie są konieczne. Paradoksalnie to, co mówił Weber w swoim wykładzie, sprawdza się też w teologii. Ona także, jak każda nauka, wymaga odpowiedniej metody i zamiłowania, tyle że jej zamiłowaniem jest wiara, teologiczna cnota wiary, jakiej wymaga sam przedmiot tej nauki.

W przeszłości interwencje nauczającego Kościoła dotyczyły w pierwszym rzędzie kwestii wiary i ewentualnych błędów z nią związanych. Wydaje się, że czasy nowożytne pozwoliły wyrazić coraz bardziej precyzyjnie, że także metoda pozostaje w ścisłej relacji z wiarą. W swej naturze epistemologicznej wypływa z samej wiary. Oczywiście, od pierwszych wieków chrześcijaństwa żaden szanujący się teolog nie podawał w wątpliwość faktu, że metoda nauk teologicznych musi odpowiadać prawdom wiary objawionej, którym teologia służy. Jednak Kościół bardziej niż podawać wskazania metodologiczne, strzegł depozytu wiary i odrzucał błędy z nim związane, pozostawiając poniekąd kwestie metodologiczne samej kompetencji teologa i szkół teologicznych. W czasach nam bliższych rozwinęła się głębiej świadomość odpowiedzialności eklezjalnej, wynikająca z tego stanu rzeczy.

Trzeba też zauważyć, że w przeszłości, mimo rozwoju szkół i ich metodologicznego podejścia do uprawianej nauki, w teologii można było zauważyć dość stabilną jedność metody. Oczywiście różnice między teologią franciszkańską a tomistyczną były wszystkim dobrze znane, ale pozostawały wciąż w orbicie pewnej uniwersalnej podstawowej jedności, która wypływała właśnie z jedności wiary i jej źródeł. Dominikanie i jezuici interpretowali Tomasza w sposób bardzo odmienny i trzeba przyznać, że gdy wielki komentator Jan od Świętego Tomasza OP (1589-1644) pozostawał wierny starej metodologii i bronił Akwinaty bez podjęcia dialogu ze współczesną mu myślą filozoficzną, a tym samym refleksją nad metodą, inaczej działo się w szkole jezuickiej, gdzie Francisco Suárez SJ (1548-1617) odważnie konfrontował się z nowościami filozoficznej refleksji nad metodą, a Francisco Toledo, Gregorio Valencia czy Gabriel Vázquez, by wspomnieć tylko niektórych, szli za odnową historyczno-krytyczną uprawiania teologii i studiowania jej źródeł. Mimo to jednak i jednym, i drugim było po drodze, jeśli chodzi o naturalną jedność myśli teologicznej. Te dwie, wrogie sobie szkoły nie różniły się, jeśli chodzi o pewien fundamentalny corpus metodologiczny uprawiania nauki teologicznej.

Przypomniane wyżej sobory watykańskie nie uczyniły nic więcej, jak tylko podały ogólne wskazania dotyczące metody, co do których istniała całkowita zgodność nawet w najbardziej zwaśnionych szkołach. Jak mi się wydaje, jednak po 
raz pierwszy w tak uroczystej formie zgromadzenie soborowe dotykało tego tematu, w pewnym sensie antycypując historię. Prawdziwy bowiem przełom w eklezjalnej refleksji nad metodą nastąpił dopiero w okresie posoborowym i w dużej mierze związany był z nauczaniem Kongregacji Nauki Wiary, angażując w pierwszej linii tę dykasterię rzymską.

\section{Nowa sytuacja posoborowa}

W teologii posoborowej pojawiły się i wciąż rodzą się nowe kierunki myśli o wierze. Całe dziesięciolecia zostały naznaczone teologią praktyczną, do której zaliczyłbym teologię wyzwolenia ${ }^{26}$, ale i trochę dziś już zapomniane teologię polityczną ${ }^{27}$, teologię rozwoju ${ }^{28}$ itp. Zrodziła się teologia feministyczna, ale i teologia religii czy pluralizmu religijnego. Obok teologii religii prężnie rozwija się teologia Izraela, ludu Starego Przymierza. Dziś jesteśmy ponadto świadkami dynamicznego rozwoju teologii kontynentalnych i narodowych. To, czym kiedyś była czarna teologia ${ }^{29}$, dziś jest teologia afrykańska ${ }^{30}$, obok której plasuje się bardzo ożywiona myśl teologii azjatyckiej ${ }^{31}$. Postulat teologii kontekstualnej ${ }^{32}$ jest coraz mocniejszy, posuwa się aż do tez typu: nie ma innej teologii, jak tylko kontekstualna, zakorzeniona w kontekście lokalnego Kościoła, z całym bagażem problemów, jakie to stawia przed teologią. Ta wielość teologii przywołała na nowo na wokandę dyskusji temat metodologii. Można powiedzieć, że każdy nowy kierunek posoborowy, bardziej niż to miało miejsce w rozwoju teologii w przeszłości, proponował i rozpracowywał także nową wizję metodologiczną. To sprawiło, że mamy dziś do czynienia z nader przyśpieszoną refleksją nad metodą.

Taki stan rzeczy wiąże się z sytuacją myśli nowożytnej, która coraz bardziej oddala się od jedności myślenia i jedności recta ratio, optując za skrajną wręcz różnorodnością. Można rzec, że najwyższą wartością myśli nowożytnej jest jej

${ }^{26}$ Por. G. Gutiérrez, Teología de la liberación: perspectivas, Salamanca 1971; thum. ang. A theology of liberation: history, politics, and salvation, Maryknoll 1988; R. Oliveros, Liberación y teología: génesis y crecimiento de una reflexión (1966-1976), Lima 1980; P. Berryman, Teología de la liberación: los hechos esenciales en torno al movimiento revolucionario en América Latina y otros lugares, México 1989.

${ }^{27}$ Por. J. B. Metz, Zur Theologie der Welt, Mainz 1973; tenże, Zum Begriff der neuen politischen Theologie: 1967-1997, Mainz 1997.

${ }^{28}$ Por. M. Flick, Z. Alszeghy, Metodologia per una teologia dello sviluppo, Brescia 1970, Giornale di Teologia, 42.

${ }^{29}$ Por. R. Gibellini, Teologia nera, Brescia 1978, Giornale di Teologia, 109.

${ }^{30}$ Por. Percorsi di teologia africana, a cura di R. Gibellini, Brescia 1994, Giornale di Teologia, 226.

${ }^{31}$ Por. M. Amaladoss, R. Gibellini, Teologia in Asia, Brescia 2006, Giornale di Teologia, 322.

${ }^{32}$ Por. S. B. Bevans, Models of contextual theology, Maryknoll 2002; R. J. Schreiter, Constructing local theologies, London 1985; C. Sedmak, R. J. Schreiter, Doing local theology: a guide for artisans of a new humanity, Maryknoll 2002. 
postulat pluralizmu, różnorodności, który musi prowadzić do fragmentaryzacji myśli. Dawno już bowiem został pogrzebany ten wspólny denominator ludzkiej myśli, jakim dla nauk była metafizyka klasyczna. Dla klasycznych szkół teologicznych była ona zawsze jedną z tych podstaw kwestii metody, bez których teologia nie mogłaby być prawdziwie intellectus fidei. Dziś sytuacja teologii jest nowa i wymaga dogłębnej i odnowionej refleksji nad metodą.

Żyjemy w czasie, w którym króluje pluralizm ${ }^{33}$, nowa prężnie rozwijająca się wartość, niosąca ze sobą zarazem nowe ryzyko fragmentaryzacji. Dla zilustrowania tej mentalności chciałbym zacytować tu diagnozę siostry Elizabeth Johnson CSJ, amerykańskiej teolog z Fordham University, autorki książki Quest for the living God: mapping frontiers in the theology of God. Nie podejmując dyskusji z tą współczesną autorką, wspomnę tylko to, co sama pisze w odpowiedzi na notyfikację błędów doktrynalnych, jaką otrzymała na temat swojej książki od Konferencji Biskupów Stanów Zjednoczonych Ameryki ${ }^{34}$. Autorka zauważa, że mamy dziś do czynienia ze swoistym puzzle teologii, które składają się na collage pozycji, szkół i tendencji teologicznych, używając najróżniejszych szkół filozoficznych, nie będąc do żadnej z nich przywiązane (,employs different philosophies, while not being tied to any one") i pracując różnymi metodami: dedukcyjną, indukcyjną, transcendentalną, porównawczą, hermeneutyczną ${ }^{35}$. Ta różnorodność jest według niej prawdziwą wartością teologii i jej poszukiwań. Co więcej, według Johnson ten stan rzeczy nie różni zbytnio nowożytności od przeszłości. Sama Johnson wydaje się przykładać mniej wagi do jedności wiary, uważając, że jej książka jako dzieło teologiczne nie chce prezentować całej wiary Kościoła, i w tym sensie krytyka braków doktrynalnych dzieła jest bezpodstawna.

Mogłoby się wydawać, że autorzy tacy jak Johnson nie mówią nic nowego w porównaniu z tym, co już dawno, zaraz pod Soborze Watykańskim II, głosił wielki Karl Rahner (1904-1984). W swojej encyklopedii teologicznej Sacramentum mundi pisał: „Teologia stała się wieloma teologiami” i „dziś istnieje nowy pluralizm teologiczny, który nie może być sprowadzony do jedności”. Na pierwszy rzut oka to stwierdzenie mogłoby się wydawać dość ryzykowne, ale Rahner dodawał rzecz bardzo ważną, powiedziałbym wiążącą dla teologii każdego czasu: ,jeśli te nowe teologie chcą być chrześcijańskie i katolickie, muszą opierać się na odwiecznym wyznaniu wiary Kościoła, w posłuszeństwie wiary". Jeśli dziś, w praktyce, dla wielu jedna tylko teologia już nie istnieje, a istnieją jedynie teologie w liczbie mnogiej, to oznacza to, że nie istnieje też jedna tylko metoda, a jedynie różnorakie metodologie w zależności od uprawianej teologii. Trzeba się jednak zastanowić, czy teologia współczesna bierze na serio to, o czym mówił Karl Rahner. Pewna jedność nie może

\footnotetext{
${ }^{33}$ Por. B. Lonergan, Doctrinal pluralism, Milwaukee 1971.

${ }^{34}$ Statement z 30 marca 2011.

${ }^{35}$ To speak rightly for the living God, „Origins” 41 (2011) z. 9, s. 129-147, tu n. 3, s. 135.
} 
być całkowicie zamazana, zapomniana, zatracona: chodzi tu o jedność wiary, bez której nie ma eklezjalnej nauki wiary, nie ma teologii.

Nowość nauczania Kongregacji Nauki Wiary

Odnowiona w duchu Soboru Kongregacja Nauki Wiary była konfrontowana z kwestią metody właściwie od pierwszego dziesięciolecia posoborowego. Pierwszy znaczący dokument, który skądinąd zmieniał cały styl nauczania Kongregacji, to deklaracja Misterium Ecclesiae ${ }^{36}$. Nie możemy naświetlić tu historycznego kontekstu tego dokumentu skierowanego do całego Kościoła, ale jak można się domyślać, zrodził się on w odpowiedzi na refleksje teologiczne Hansa Künga. Ten tekst z roku 1973 już dotyka paru kwestii metodologicznych, związanych z koncepcją dogmatu i wartościowaniem propozycji dogmatycznych, jak również z relacją teologii do historii, a co za tym idzie, i do nauk historycznych. Jest to bardzo ogólna wypowiedź, zakorzeniona w Tradycji, która przyjmuje za jeszcze istniejący wspólny mianownik metodologiczny całej teologii powołanej do interpretowania słowa Bożego w Kościele.

Najważniejszym momentem nauczania Kongregacji Nauki Wiary o metodzie teologicznej jest niewątpliwie dokument z 24 maja 1990 roku, instrukcja Donum veritatis o powołaniu teologa w Kościele, za którą szła publikacja instrukcji dyscyplinarnej Il Concilio Vaticano II o niektórych aspektach wykorzystania środków społecznego przekazu w promocji nauki wiary z 30 marca 1992 roku. Przez te dwa dokumenty dotykamy samego centrum prefektury kardynała Josepha Ratzingera, który niewątpliwie był odnowicielem i prawdziwym reformatorem Kongregacji, jej stylu nauczania i pracy w duchu soborowym.

Zanim jednak poświęcę trochę uwagi Donum veritatis, chciałbym spojrzeć na całościowy rozwój nauczania Kongregacji w tej sferze, w szczególności w przypadkach, w których dykasteria negatywnie oceniła metodę konkretnych teologów. Wydaje mi się, że mamy tu do czynienia z nowym fenomenem w nauczaniu Kościoła. Nie chodzi już bowiem o wskazówki pozytywne i dość generalne na temat tego, jak uprawiać teologię. Chodzi raczej o ocenę konkretnej metody naukowej, zaaplikowanej w refleksji teologa, z punktu widzenia doktrynalnego. Pojedyncza metoda naukowa zostaje tu poddana osądowi doktrynalnemu.

Przytoczę parę przypadków, które stanowią swego rodzaju novum w relacji między Urzędem Nauczycielskim Kościoła a konkretnymi metodami teologicznymi.

1. Długoletnie studium nauczania teologicznego Hansa Künga, jak mi się wydaje, po raz pierwszy doprowadziło do jasnej wypowiedzi na temat oceny metody

${ }^{36}$ Por. G. Sala, Dogma e storia nella dichiarazione „, Mysterium Ecclesiae”, Bologna 1976, Nuovi Saggi Teologici. Collana Interconfessionale per la Promozione della Ricerca Teologica, 10. 
teologicznej wypracowanej przez pojedynczego teologa. Wartość metody była tu przywołana przez regułę generalną, która mówiła:

Urząd Nauczycielski Kościoła, by wypełnić to ważne zadanie, które tylko jemu zostało powierzone (Konst. Dei verbum, 10), wykorzystuje poszukiwania teologów, przede wszystkim tych, którzy otrzymali w Kościele misję nauczania; a więc także oni są ustanowieni w jakiś sposób nauczycielami wiary. Teologowie w swoich badaniach, tak jak przedstawiciele innych nauk, korzystają z uprawnionej wolności naukowej, jednak w granicach metody świętej teologii, starając się dojść, we właściwy im sposób, do tego samego celu, co Urząd Nauczycielski: zachowywać, coraz głębiej przenikać, wykładać, nauczać, bronić świętego depozytu objawienia; oświecać więc życie Kościoła i ludzkości za pośrednictwem prawdy Bożej.

Jest więc konieczne, by zgłębianie i nauczanie doktryny katolickiej zawsze promieniowało wiernością wobec Urzędu Nauczycielskiego Kościoła, ponieważ nikt nie może uprawiać teologii inaczej, jak tylko w ścisłej łączności z misją nauczania prawdy, za którą jest odpowiedzialny tylko Kościół ${ }^{37}$. Pomniejszając tę wierność, wyrządza się szkodę także wiernym, którzy w wyznawaniu wiary, otrzymanej od Boga za pośrednictwem Kościoła, mają święte prawo otrzymywania integralnego słowa Bożego; oczekuje się więc, że zostaną uchronieni od błędów pomniejszających ich wiarę ${ }^{38}$.

Metoda jest tu widziana przez pryzmat relacji teologii do Magisterium Kościoła, czyli dotyka jednego tylko, acz wiążącego, aspektu całej problematyki.

2. Później, przy okazji innego studium, w roku 1986, w sposób raczej ogólnikowy, ale nie bez znaczenia, Kongregacja przywoływała jedność organiczną prawdziwej teologii, która nie tylko w swoich treściach, ale także w metodzie jest powołana do nieodzownej wierności Magisterium Kościoła. U samego początku listu do jednego z teologów moralistów pisano:

Celem niniejszego Listu jest powiadomienie Profesora, że Kongregacja podtrzymuje swoje stanowisko, według którego ten, kto nie zgadza się z Urzędem Nauczycielskim, nie może być ani zdolny, ani dopuszczony do nauczania teologii katolickiej. $Z$ tego powodu nie akceptuje ona [rozwiązań, które by ograniczały] jedność autentycznej teologii katolickiej, jedność, która jest wewnętrznie połączona, w swojej treści i metodzie, z wiernością Urzędowi Nauczycielskiemu Kościoła $^{39}$.

Ponownie dotknięty jest tu problem relacji między teologiem a Magisterium jako fundamentalny aspekt właściwej metody teologicznej.

\footnotetext{
${ }^{37}$ Por. Jan Paweł II, konst. Sapientia christiana, 70, AAS 71 (1979), s. 493; tenże, enc. Redemptor hominis, 19, AAS 71 (1979), s. 308.

${ }^{38}$ Kongregacja Nauki Wiary, Deklaracja o niektórych aspektach..., cpvv. 2-3.

${ }^{39}$ Taż, List do Ojca Charles'a Currana, 25 lipca 1986, AAS 79 (1987) 116-118, cpv. 2.
} 
3. W podobnej sytuacji, przy okazji analizy jednego z dzieł teologii moralnej, Kongregacja oceniała, że konkretne błędy doktrynalne, obecne w książce, były zakorzenione ostatecznie w błędnej metodzie:

\begin{abstract}
Dokładna analiza tekstu wykazała jednak, że w wielu poważnych i zasadniczych kwestiach autor nie zgadza się nie tylko z najnowszym nauczaniem Urzędu Nauczycielskiego, ale także z tradycyjną nauką Kościoła. Niezgodności te dotyczą ogólnej koncepcji płciowości, sposobu rozumienia osoby ludzkiej w jej relacji do innych osób i do Boga Stwórcy, a także moralnej oceny pewnych konkretnych form zachowań seksualnych. Mają one swoje istotne źródło w nieadekwatnym, a niekiedy błędnym podejściu do problemu na poziomie metody teologicznej ${ }^{40}$.
\end{abstract}

Trzeba przyznać, że przytoczone powyżej przykłady są raczej ogólnikowym wspomnieniem niektórych podstawowych wykładników metody teologicznej, bez pogłębionej wykładni metodologicznej tej nauki. W pewnym sensie przywołane są en passant $\mathrm{w}$ dokumentach, które skupiają się na wyliczeniu błędów doktrynalnych obecnych w studiowanych tekstach. Co więcej, teksty skupiają się na relacji teologa do Magisterium, temacie, który otrzyma swoją pogłębioną wykładnię we wspomnianej instrukcji Donum veritatis ${ }^{41}$.

Dopiero w czasie nam o wiele bliższym, bo całkiem niedawno, przy okazji oficjalnego studium książek dwóch ojców jezuitów, Rogera Haighta i Jona Sobrino, Kongregacja chyba po raz pierwszy w sposób pogłębiony i systematyczny wypowiedziała się na temat konkretnych metod teologicznych.

4. W pierwszym przypadku chodzi o Notification na temat dzieła Jesus Symbol of God amerykańskiego jezuity Rogera Haighta, z 14 grudnia 2004 roku $^{42}$. Jest to chyba pierwszy przypadek, gdzie osąd metody pojedynczego teologa zostaje wyrażony jeszcze przed wskazaniem konkretnych błędów doktrynalnych ${ }^{43}$. Jak mówiłem, w przeszłości kontestowano pojedyncze błędy doktrynalne, kwalifikując ich poziom niezgodności z prawdą. Tu krytyka błędów rozpoczyna się od krytyki samej metody. Do tej pory można było przyjąć, że metoda jest w pewnym sensie neutralna, należy do osobistych, kompetentnych wyborów teologa. W ocenie teologii amerykańskiego autora Kongregacja po raz pierwszy mówi jasno, że jego pierwszym błędem jest metoda. W szczególności stwierdza się, że metoda ojca Haighta, proponując korelację między danymi wiary a kulturą współczesną, w rzeczywistości podporządkowuje prawdy wiary ich czytelności kulturowej. Innymi słowy, przyjęta metoda brała

${ }^{40}$ Informacja o ksiażce „, The Sexual Creators, An Ethical proposal for Concerned Christians” (University Press of America, Lanham-New York-London 1986) Ojca André Guindon OMI, 31 stycznia 1992, I, n. 1, cpv. 3.

${ }^{41}$ Por. Kongregacja Nauki Wiary, Instrukcja Donum veritatis, IV, 21-41.

${ }^{42}$ Por. Notification on the book ,,Jesus Symbol of God” by Father Roger Haight S.J., 13 grudnia 2004.

43 „I. Theological method" (Notification, n. I). 
górę nad prawdami wiary, przewyższała je, a nie dostosowywała się do wymogów tychże prawd. Dlatego autor deklarował, że z powodu współczesnej świadomości pluralistycznej nie można utrzymywać twierdzenia, że chrześcijaństwo jest religią przewyższającą inne religie i że Chrystus jest absolutnym centrum, któremu byłyby podporządkowane inne mediacje historyczne. We współczesnej kulturze niemożliwe jest myśleć, że jedna z religii pretenduje do bycia centrum, do którego wszystkie inne są skierowane i któremu są podporządkowane ${ }^{44}$. To konfrontacja z konkretną kulturą już na poziomie metody spowodowała konsekwentne błędy chrystologiczne.

5. W drugim przypadku, Notificación na temat dzieł jezuickiego chrystologa ojca Jona Sobrino (26 listopad 2006), podobnie rozpoczyna się od krytyki założeń metodologicznych, zanim jeszcze, w konsekwencji metody, zostaną wskazane konkretne błędy w studiowanych pismach. Można przypuszczać, że właściwa metoda aplikowana w teologii ustrzegłaby przed ewentualnymi błędami, natomiast błędna metoda może stać się niechybnie źródłem bezdroży w samych studiowanych treściach ${ }^{45}$.

W metodzie ojca Sobrino zostaje negatywnie ocenione to, co stanowi jego „główny, podstawowy kierunek” (,dirección fundamental”). Dla autora Jesucristo liberador podstawowym miejscem teologicznym, pierwszorzędnym locus theologicus jest „Iglesia de los pobres”. Takiemu przewartościowaniu metodologicznemu Kongregacja przeciwstawia prawdę stanowiącą o istocie metody teologicznej, to znaczy podstawowe źródło teologiczne, miejsce poznania teologicznego, jakim jest wiara Kościoła. W niej znajduje się właściwe usytuowanie każdego innego miejsca teologicznego.

W swojej diagnozie metody Kongregacja podejmuje klasyczny temat loci theologici, które są otwarte na różnorodność źródeł, ale i wymagają określonego porządku, gdzie podstawowym źródłem teologii może pozostawać jedynie wiara Kościoła. W ten sposób nie przekreśla się ani nie zatraca drugorzędnych albo pomocniczych miejsc teologicznych, ale jedynie ukierunkowuje takie prawomocne źródła na pierwsze i podstawowe źródło poznania teologicznego, jakim jest wiara ${ }^{46}$.

${ }^{44}$ Por. R. Haight, Jesus, symbol of God, Maryknoll 1999, s. 333. Ten teolog jest autorem także swego rodzaju traktatu metodologicznego teologii: Dynamics of theology, Maryknoll 1990, 2001².

${ }^{45}$ „I. Presupuestos metodológicos” (Notificación, n. I).

${ }^{46}$ W sposób bardzo ogólny, co nie znaczy niezdecydowany, powraca kwestia źródeł teologicznych. Jak wiadomo, po raz pierwszy w sposób naukowy zostały one usystematyzowane przez dominikanina Melchiora Cano w jego dziele De locis theologicis libri duodecim. Według tomisty miejsca teologiczne można usystematyzować w dziesięciu kategoriach, tworzących dwie podstawowe grupy: 1) właściwe źródła poznania teologicznego (loci theologici proprii) i 2) te źródła, które teologia zapożycza od innych dyscyplin (loci theologici alieni). W pierwszej grupie znajdują się następujące źródła: zawierające Objawienie (revelationem constituentes), to jest Scriptura i Traditio, oraz zawierające interpretację Objawienia (revelationis interpretationem continentes), to jest Ecclesia catholica, Concilia, Ecclesia romana, Patres, scholastici theologi. W drugiej grupie źródeł Cano przewidywał przede wszystkim miejsca dla ratio naturalis, co można tłumaczyć jako 
W tych ostatnich wypowiedziach Kościół, chyba bezprecedensowo, mówi konkretnemu teologowi w dobitny sposób: użyta metoda jest błędna, posiada braki, musi być poprawiona. Takie stanowisko na nowo otwiera naglącą aktualnie kwestię epistemologiczną teologii, problem jej właściwych metod. Z nową mocą powraca dziś pytanie, które postawiliśmy u początku tej refleksji: czy Kościół ma prawo krytykować metodę jednego ze swoich teologów albo metodę całej grupy czy szkoły teologicznej?

Jak już wspominałem, do tej pory wydawało się, że w teologii przyjmowano generalnie pewną wspólną metodologiczną podstawę niezbędną do tego, by teologia była teologią. Prawdą jest, że już nominalizm, a później iluminizm lansował zdecydowane nowości w metodologii, ale mimo to jednak katolickie szkoły teologiczne pozostawały jeszcze do czasów soborowych w orbicie takiego niezbędnego wspólnego denominatora na poziomie metodologii, oczywiście przy nieodzownej odnowie, jaką promowały ruchy biblijny, liturgiczny, ekumeniczny, i jakim był powrót do źródeł, w szczególności do ojców Kościoła, rozwinięty w czasie przygotowującym ostatnią

recta ratio, o której naucza Jan Paweł II w Fides et ratio, zaraz po niej philosophi, wśród których pierwsze miejsce według Cano zajmował Arystoteles, i historia humana.

Nie możemy w tym miejscu podjąć dyskusji, na ile taka forma usystematyzowania miejsc może być przyjęta powszechnie. Pierwowzoru dla Cano można się doszukiwać u jego mistrza Tomasza z Akwinu, który wylicza wśród źródeł autorytet Pisma Świętego, doktorów Kościoła i filozofów (Summa theologiae, I, q. 1, art. 8, ad 2um). Są jednak i tacy, jak swego czasu ojciec Chenu, którzy uważają, że kwalifikacja podana przez Cano nie ma nic wspólnego z myślą Tomasza, który takiego porządku nie podał, a kwalifikacja sama w sobie niosłaby niebezpieczne ryzyko skostnienia teologii, która nie może być tylko zestawianiem źródeł. Być może dlatego najnowszy dokument Międzynarodowej Komisji Teologicznej ogranicza się do powiedzenia na temat źródeł tylko dwóch zdań: „w teologii katolickiej wiele zastanawiano się nad loci teologii, czyli podstawowymi punktami odniesienia dla zadania teologicznego. Ważne jest, aby poznać nie tylko loci, ale także ich względny ciężar oraz relację między nimi” (n. 20), choć później w toku rozumowania sam dokument przyjmuje w znacznej mierze porządek miejsc teologicznych, jaki podał Cano.

W każdym razie trzeba przyznać, że rozumienie miejsc teologicznych przez Cano jest nad wyraz nowoczesne i w pewnych elementach wyprzedza historię w rozumieniu i kwalifikacji miejsc. Jeśli są one dobrze zrozumiane i utrzymane we właściwej relacji jedne wobec drugich, nie prowadzą do skostnienia teologii, a mogą służyć za swego rodzaju rdzeń nieodzowny do właściwego poznania teologicznego. Są wskazaniem podstawowego punktu odniesienia dla teologii (por. Teologia dzisiaj, nn. 27 i 35). Wydaje się, że wskazuje na to także tekst Kongregacji o dziełach ojca Sobrino, gdy używa pojęcia „miejsce teologiczne”.

Co więcej, dziesięć miejsc teologicznych to liczba umowna i sam Cano, jak mi się wydaje, nie miałby nic przeciwko, by sprecyzować lepiej i rozszerzyć przede wszystkim miejsca pomocnicze. Wydaje mi się, że dziś należy pomyśleć o bardziej specyficznym rozszerzeniu i sprecyzowaniu miejsc. Uważam, że dziś trzeba lepiej zastanowić się nad statusem takich miejsc, jak: 1) liturgia i życie liturgiczne Kościoła; 2) życie świętych (hagiografia) i teologia świętych; 3) prawo kanoniczne (łacińskie i wschodnie); 4) doświadczenia mistyczne i objawienia prywatne; 5) sztuka chrześcijańska w całej swojej różnorodności; 6) kultura; i - last but not least - 7) znaki czasu (por. Sobór Watykański II, konst. Gaudium et spes, AAS 58 [1996], 4, 44). Większość z nich znalazłaby się wśród miejsc pomocniczych według schematu Cano, co nie znaczy, że nie mają one znaczącej wagi dla teologii. 
odnowę soborową. Metoda wydawała się kwestią profesjonalizmu teologicznego, niejako niezbędnym wspólnym fundamentem badań teologicznych.

Z drugiej strony, jeśli Kongregacja zaczęła wypowiadać się w sprawach metody, to oczywiście nie mogłoby to oznaczać, że podważa kompetencję naukową teologa, z którym podjęła dialog, czy że ma wątpliwości co do jego profesjonalizmu . Jest to wykluczone; jeśli Kongregacja zainteresowała się pracą teologa, to oznacza raczej, że profesjonalnie teolog ten reprezentuje taki poziom myśli, który może stać się obiektem studium w wymiarze całego Kościoła powszechnego. Nie ma wątpliwości: niekompetencją Kongregacja się nie zajmuje.

$\mathrm{Z}$ tego należy zatem, jak mi się wydaje, wyciągnąć inny wniosek. Myślę, że to nowe zainteresowanie metodą ze strony Kościoła, a w szczególności Kongregacji Nauki Wiary, świadczy o tym, że nastąpiła jakościowo nowa refleksja w tej sferze, że jesteśmy świadkami pewnego rozwoju myśli dotyczącej metody teologicznej.

$\mathrm{Z}$ jednej strony, coraz częściej odchodzi się od postrzegania jedności co do wspólnej bazy metodologicznej w szeregach teologów. Może to wyrastać z jej ubogacenia interdyscyplinarnego, z coraz żywszej konfrontacji z naukami współczesnymi, z bardzo ożywionym dialogiem z coraz to nowymi szkołami filozoficznymi. Ale może to wywołać także ryzyko zaprzepaszczenia czegoś, co w teologii nieodzowne. Interdyscyplinarność nie może zaprzepaścić samej istoty teologii, a co za tym idzie, także istoty jej metody. Gdyby teologia stosowała tylko kryteria i normy metodologiczne nauk socjologicznych czy politycznych, i tym podporządkowała swoje jestestwo, albo gdyby bardziej niż metodę teologiczną ceniła analizę psychologiczną, czy skupiałaby się jedynie na metodzie historyczno-krytycznej, mogłaby dojść do interesujących tez, tyle że ryzykowałaby zatracenie samej natury teologii jako nauki o Objawieniu, nauki wiary. Z niewłaściwej metody rodzą się bowiem i biblicyzmy, i socjologizmy itd.

Jeśli coraz bardziej widoczny wśród teologów brak zgody co do niezbędnych fundamentów metody, pogłębiający się w czasach posoborowych, był okazją historyczną do refleksji Kościoła nad metodą, myślę, że w tym trudnym kontekście dochodziło coraz bardziej do głosu przekonanie, że metoda teologii ma do czynienia z samą doktryną wiary, nie jest neutralnym, tylko osobistym wyborem pojedynczego teologa, ale wynika $\mathrm{z}$ dynamiki Objawienia i w pewnym sensie jest już w swoich ogólnych kształtach zawarta w Objawieniu. Rodzi się w ten sposób coraz jaśniejsza świadomość, że istnieje wymiar doktrynalny metody teologicznej, że metoda teologiczna posiada znaczenie doktrynalne, które może być przedmiotem oceny doktrynalnej ze strony Kościoła, podobnie jak ocenie doktrynalnej podlegają błędne twierdzenia teologiczne. Taka teza rodzi jednak wiele pytań, bowiem metoda jest także kwestią epistemologiczną, jest jakby pierwszym terenem, na którym wciąż musi dochodzić do konfrontacji teologa z innymi naukami, przede wszystkim ze współczesnym rozwojem metod interpretacji, nauk epistemologicznych itd.

Wydaje mi się, że byłoby dość banalnym błędem utrzymywać, że metoda teologiczna we wszystkich swoich konkretnych rozwiązaniach jest częścią doktryny 
wiary. Metoda bowiem należy do sfery intelligentia, do sfery rozumu. Niemniej należy do zadań rozumu, który jest oświecony wiarą, a w tym sensie trzeba uznać, że posiada pewien rdzeń doktrynalny. Także metoda zakorzeniona jest w doktrynie wiary. Współczesne wypowiedzi Kongregacji Nauki Wiary potwierdzają tę odnowioną perspektywę, dają wyraz odnowionej świadomości na temat wymiaru doktrynalnego metody aplikowanej w nauce teologicznej.

Jedno jest pewne: metoda teologiczna musi powrócić na drogę pogłębionej i systematycznej refleksji teologicznej, prowadzonej z troską o depozyt wiary, o to podstawowe miejsce teologiczne, jakim jest wiara Kościoła. Forma poznania teologicznego nie może być oderwana od samego przesłania teologii, od jej przedmiotu i podmiotu, jakimi jest sam Bóg Objawienia. Struktura katedry teologicznej, jej rusztowania w konstruowaniu myśli muszą w swej istocie być dostosowane do form budowli. To źródła teologii nadają metodzie jej ostateczną i decydującą formę, a nie metoda formuje źródła ${ }^{47}$. Jeśli teologia jest nauką wiary ${ }^{48}$, to i jej metoda nie może być całkowicie oderwana od źródeł tejże wiary. Nowe metody nie mogą być aplikowane w refleksji teologicznej bezkrytycznie, jakby neutralnie i niezależnie od depozytu wiary. To właśnie depozyt wiary ukierunkowuje metody, które będą zdolne wypowiedzieć go także wobec współczesnego świata.

\section{Eklezjalna kompetencja w kwestiach metody teologii}

Jeżeli Kongregacja w swojej misji odpowiedzialności za doktrynę katolicką wypowiada się na temat metody teologicznej, trzeba $\mathrm{z}$ tego wnosić, że metoda teologii przedstawia wartość doktrynalną, której należy bronić i przestrzegać. O ile dotychczas notowaliśmy względną powściągliwość w ocenie metody, to dziś coraz bardziej zdecydowanie rysuje się podejmowanie kwestii metody już nie jako jednej metody, ale jako metod teologii.

Teologia jako nauka eklezjalna ${ }^{49}$ otrzymała w rzeczywistości jeden dokument Kongregacji całościowo poświęcony powołaniu teologii. Jest to, jak wiadomo, instrukcja o powołaniu teologa w Kościele Donum veritatis. Jest to również swego rodzaju kamień milowy w nauczaniu kościelnym o tym, czym jest i czym powinna być teologia katolicka. Jednak dokładniejszą analizę tego dokumentu z powodu czasu musimy pozostawić na inną okazję.

${ }^{47} \mathrm{~W}$ tym świetle Kongregacja zauważała braki w chrystologii Jona Sobrino, dotyczące braku odpowiedniej uwagi poświęconej źródłom normatywnym (por. Notificación, 3).

${ }^{48}$ Dla rozwinięcia niektórych aspektów tej kwestii por. K. Charamsa, Wiara i komunikacja wiary we wspótczesnym świecie, „Studia Pelplińskie” 2013 (w druku).

${ }^{49}$ Por. A. Napiórkowski, ,,Misterium communionis”. Eklezjalny paradygmat dziejów zbawienia, Kraków 2006. 
Pokrótce, Donum veritatis pragnie być dokumentem, który pozytywnie formuluje eklezjalną wizję teologii rozpoznanej jako prawdziwe powołanie w Kościele ${ }^{50}$. Niemniej w tekście dużo uwagi poświęcono szczegółowej kwestii relacji i współpracy między teologią a Magisterium Kościoła ${ }^{51}$, a to z przyczyn historycznych, które leżą u źródeł dokumentu. Jest on bowiem także odpowiedzią na nowy fenomen konfliktów między teologią a Urzędem Nauczycielskim ${ }^{52}$. Chodzi tu o zupełnie nowy fenomen w relacjach teologów z hierarchią Kościoła w tym sensie, że o ile w przeszłości można było napotkać pojedyncze rozbieżności między teologiem a Magisterium, to $\mathrm{w}$ czasie posoborowym mamy do czynienia z nowymi przypadkami grupowej i systematycznej kontestacji Magisterium: już nie pojedynczy teolog prezentuje swoją opozycję wobec nauczania Magisterium, ale całe grupy, szkoły czy stowarzyszenia teologiczne przyjmują postawę sprzeciwu wobec Urzędu Nauczycielskiego czy wobec konkretnych aktów nauczania tegoż Urzędu. Co więcej, nie dzieje się to na roztropnej drodze wewnętrznej dyskusji w Kościele, gdzie teolog jest w pewnym sensie nawet zobowiązany przedstawić kompetentnej władzy kościelnej własne wątpliwości co do konkretnej wypowiedzi czy aktu nauczania, ale w przestrzeni publicznej, najczęściej przez środki masowego przekazu. Tak rodziły się i wciąż rodzą deklaracje opozycji wobec Magisterium, podpisane nierzadko przez dziesiątki, a ostatnio nawet setki teologów. Dlatego też temat relacji między teologią a Magisterium pozostaje w pewnym sensie dominujący w instrukcji o powołaniu teologa w Kościele ${ }^{53}$.

\section{Perspektywy przyszłej refleksji eklezjalnej na temat metody teologicznej}

Współczesna, posoborowa sytuacja teologii, jak również konsekwentne wypowiedzi Urzędu Nauczycielskiego Kościoła skłaniają nas do kilku refleksji końcowych, które można ująć w następujący sposób:

1. Metoda teologiczna nie jest całkowicie neutralna wobec wiary, nie jest oderwana i niezależna od wiary. Nie może być pojmowana jako prywatna decyzja naukowca,

${ }^{50}$ Por. II, 6-12: Powolanie teologa.

${ }^{51}$ Por. tamże, IV. A, 21-31.

${ }^{52}$ Por. tamże, IV. B, 32-41.

${ }^{53}$ Powracając do myśli przewodniej o służbie Słowu, w duchu komunii eklezjalnej, „kończąc [...] Instrukcję, Kongregacja Nauki Wiary usilnie zachęca Biskupów do utrzymywania i rozwijania opartych na zaufaniu kontaktów z teologami w klimacie wspólnej troski o przyjęcie Słowa i służenie $\mathrm{Mu}$ w komunii miłości, co pozwoli łatwiej przezwyciężyć pewne przeszkody związane z kondycją ludzkiej egzystencji na ziemi. W ten sposób wszyscy będą sługami Słowa Bożego i Ludu Bożego, aby ten lud, trwając w nauce prawdy i wolności, jaką otrzymał od początku, trwał także w Synu i w Ojcu oraz otrzymał życie wieczne, będące wypełnieniem Obietnicy (por. 1 J 2, 24-25)” (n. 42). 
bo w swych podstawowych wymiarach wypływa z samego statusu teologii jako nauki o wierze i Objawieniu.

2. Istnieje doktrynalny rdzeń metody teologicznej. Współczesność uświadamia nam coraz bardziej istnienie wymiaru doktrynalnego metody nauk teologicznych. $\mathrm{W}$ tej kwestii rodzi się wciąż otwarte pytanie dotyczące tego, w jakiej mierze i na ile wolno nam oceniać metody także z punktu widzenia doktrynalnego.

3. Proces rozeznawania metod jest procesem teologicznym i eklezjalnym i wymaga czasu na dogłębną refleksję. Paradygmatem tego dojrzewania był proces konfrontacji wiary i teologii z myślą i metafizyką grecką. Takie rozeznanie jest potrzebne do rozpoznania właściwej metody, odpowiadającej wymogom depozytu wiary, a także do ewentualnego poprawienia niedoskonałości racjonalnych metod w świetle wymogów prawd wiary, jak również do odrzucenia metod, które nie mogą służyć wierze, w przypadku, gdyby ich użycie zaprzepaszczało albo dewaluowało prawdy absolutne wiary.

4. Odróżnienie tego, co niezbędne we właściwej metodzie teologicznej, od tego, co jest z nią sprzeczne, jest jednym z naglących pytań postawionych przed teologią współczesną. Taki proces potrzebuje dziś systematycznego przemyślenia. W pewnym sensie Papieska Komisja Biblijna, organ teologiczno-egzegetyczny niebędący organem Magisterium, dokonała przełomowej oceny niektórych metod w interpretacji Pisma Świętego w słynnym dokumencie L'interprétation de la Bible dans l'Église z 15 kwietnia 1993 roku $^{54}$.Ze strony Międzynarodowej Komisji Teologicznej takim wkładem do dyskusji na temat metody i samej istoty teologii był natomiast dokument Teology Today. Perspectives, Principles and Criteria, opublikowany w roku $2012^{55}$.

Warto zwrócić uwagę, że oba zacytowane dokumenty nie są wypowiedziami Kongregacji Nauki Wiary, a jedynie komisji naukowych istniejących dziś jako

${ }^{54}$ Dokument Papieskiej Komisji Biblijnej zawiera analizę metod interpretacji (n. I), począwszy od metody historyczno-krytycznej (n. I. A), po różnorakie nowe metody interpretacji (n. I. B), gdzie poruszone są kwestię metody analizy retorycznej (n. I. B. 1), narracyjnej (n. I. B. 2) i semiotycznej (n. I. B. 3), jak również metod bazujących na tradycji (n. I. C), czyli metody analizy kanonicznej (n. I. C. 1), opartej na żydowskich tradycjach interpretacji tekstów (n. I. C. 2), i tej wypływającej z historycznego znaczenia tekstów (Wirkungsgeschichte) (n. I. C. 3), wreszcie metod posługujących się naukami humanistycznymi (n. I. D): socjologicznymi (n. I. D. 1), kulturalno-antropologicznymi (n. I. D. 2), psychologicznymi i psychoanalitycznymi (n. I. D. 3), jak również metod kontekstualnych (n. I. E), teologii wyzwolenia (n. I. E. 1) i feministycznej (n. I. E. 2), skończywszy na metodach fundamentalistycznych (n. I. F). Wspólna refleksja biblistów w tymże dokumencie podaje też charakterystyki niezbędne katolickiej interpretacji tekstów (n. III).

${ }^{55}$ Dokument ten podaje dwanaście kryteriów właściwego uprawiania teologii jako nauki eklezjalnej. Na ten temat pozwolę sobie odesłać do moich dwóch publikacji: La teología vista por los teólogos. Una introducción al Documento de la Comisión teológica internacional, „Ecclesia” 4 (2012), s. 229-249, i Teologia vista dai teologi. Un'introduzione al documento della Commissione Teologica Internazionale, „Rivista di Ascetica e Mistica” 1 (2013). 
organy konsultacyjne przy samej Kongregacji i pozostających od niej w znacznej mierze, przede wszystkim dotyczącej studium, niezależne. Można z tego wnosić, że całościowe ujęcie kwestii metody zostało powierzone tym instancjom naukowym, a nie organowi Magisterium. Na podstawie statusów tychże komisji można wnosić, że to sam autorytet hierarchiczny Kościoła poddał ten temat uwadze Komisji ${ }^{56}$, a nie rezerwował dla siebie wypowiedzi na temat metody. Trzeba przyznać, że w pewnym sensie to dokumenty Komisji Biblijnej i Teologicznej, a nie wprost Magisterium Kościoła otwierają perspektywy dla przyszłej poważnej refleksji nad metodą teologiczną, i można przypuszczać, że takie usytuowanie i ukierunkowanie debaty było wolą samego Magisterium, które realizuje w tej mierze właśnie swoją powściągliwą misję wobec metod teologicznych starych i nowych, interweniując tylko i wyłącznie wtedy, gdy jest to absolutnie konieczne dla zachowania integralności depozytu wiary.

5. Kościół w swoim Magisterium jest także w pewnej mierze odpowiedzialny za metodę. Na tyle, na ile metoda teologiczna jest związana z doktryną wiary, Kościół ma prawo i obowiązek strzec metody właściwej dla teologii jako eklezjalnej nauki wiary. Chodzi tu jednak o sam rdzeń metodologii, o jej podstawy, fundamenty, które stanowią o specyfice i odrębności tej nauki w panoramie innych nauk. $Z$ jednej strony owa kościelna troska o metodę musi zachować szacunek dla wolności teologicznego rozeznawania metod, $\mathrm{z}$ drugiej nie może milczeć, gdy doktrynalne prawdy wiary mogą zostać podporządkowane metodzie czy pewnym jej elementom, z ryzykiem zaprzepaszczenia prawdy objawionej.

6. Teologia jest odpowiedzialna za wciąż nowe wypracowanie metod, rozeznanie, co charakteryzuje jej wolność jako nauki. Niemniej to Magisterium Kościoła jest odpowiedzialne za wymiar doktrynalny metody uprawianej teologii. Oba elementy są ze sobą głęboko scalone i wcale nie jest łatwe ich rozdzielenie, stąd podejście do metody, a w szczególności do nowych metod aplikowanych w teologii, wymaga i od teologów, i od Kościoła pewnej powściągliwości i umiarkowania, cierpliwości, roztropności, ostrożności i ewangelijnej rozwagi. I teologowie, i Kościół mają bowiem to samo zadanie wobec słowa Bożego, które jest jakby skrótem tego wszystkiego, co Bóg myśli o sobie samym i o drogach ludzkiego dochodzenia do Jego prawdy.

${ }^{56}$ Por. Paweł VI, Motu proprio Sedula cura stanowiące nowe prawa reorganizujące Papieską Komisję Biblijną (27 czerwca 1971), 9: „Quaestiones et argumenta studio expendenda a Summo Pontifice aut a Praeside Commissionis designantur, proponentibus vel Sacra Congregatione pro Doctrina Fidei, vel Synodo Episcoporum, vel Conferentiis Episcopalibus, vel ipsa Commissione Biblica suggerentibus eiusdem Membris, vel etiam catholicis Studiorum Universitatibus et Societatibus Biblicis, salvo praescripto n. 136 Constitutionis Apostolicae Regimini Ecclesiae universae"; Jan Paweł II, Motu proprio Tredecim anni aprobujące definitywne statusy Międzynarodowej Komisji Teologicznej (6 sierpnia 1982), 9: „Quaestiones et argumenta studio expendenda a Summo Pontifice vel a Cardinali Praeside designantur. Proponi etiam possunt a Sacra Congregatione pro Doctrina Fidei, ab aliis Dicasteriis Curiae Romanae, a Synodo Episcoporum, a Conferentiis Episcopalibus. Servetur tamen praescriptum n. 136 Constitutionis Apostolicae Regimini Ecclesiae Universae". 
Powyższych kilka myśli, ujętych w ramach syntezy, bardziej niż podsumowaniem, jest perspektywą dla przyszłej refleksji, która dziś jest dla teologii nieodzowna, konieczna. Jest to refleksja, która swój podstawowy grunt znajduje w mozolnej i cierpliwej pracy teologicznej, pracy nad rozeznawaniem metod i dostosowywaniem współczesnych dróg interpretacyjnych do zadanej prawdy wiary. Jest to refleksja wymagająca dużo czasu, kompetentnych poszukiwań i ciągłej konfrontacji z myślą innych dyscyplin naukowych. Rozeznanie nowych metod nie jest kwestią automatyczną i łatwą do przewidzenia, ale wymaga, po pierwsze, dogłębnej wiedzy epistemologicznej i interdyscyplinarnej, po drugie, roztropnego oceniania wciąż nowych metod interpretacji i rodzących się szkół i kierunków filozoficznych w świetle wiary, której mogą one służyć.

Taka praca teologa nie jest jednak pracą odizolowaną od wspólnoty Kościoła, który jest domem teologii i wspólnotą, w której teolog kultywuje swoją naukę. Teologia potrzebuje czasu na rozeznanie właściwych metod, niemniej nie może odbierać wspólnocie Kościoła prawa do umiarkowanego, powściągliwego, ale wiążącego oceniania z punktu widzenia doktryny wiary coraz to bardziej różnorodnych kroków metodologicznych.

\section{Summary \\ Theology and its assignments in the light of teaching of Congregation for the Doctrine of the Faith}

The article reflects on the theology and its assignments from the point of view of its own scientific method. The coherent method of the theological speculation cannot be totally indifferent to the essential bond between theology and deposit of the faith. To this respect, the indications offered by the teaching of the Congregation for the Doctrine of the Faith in the post-conciliar time are analyzed, reflecting on the doctrinal competence field, where the Dicastery advances with a new intensity the doctrinal orientations for the correct theological method.

\section{Key words}

Theology, faith, theological method, Congregation for the Doctrine of the Faith 